書 丮

\section{編 集宮城音弥}

\section{創造性とその開発（シンポジウム）}

\section{Harold H. Anderson, editor}

(Creativity and its cultivation: Addresses presented at the interdisciplinary symposia on creativity. Michigan State Universty. New York : Harper \& Brothers, 1959, pp. 293. )

15 の論文が収められている。科学的創造性 (H. Eyring)，創造的な生活 (E.W. Sinnott), 創造性について の建築家の意見 (A. B. Dow)，創造的態度 (E. Fromm)， 創造性の特質 (R. May), 創造性の理論をめざして (C. R. Rogers), 自己実現としての創造性 (A. H. Maslow), 創造の变遷（H. A. Murray），パーソナリティーの発達 としての創造性 (H. H. Anderson), 創造力の特性 (J. P. Guilford), 創造性々問題解決 (E. R. Hilgard), 教育に 䏡ける創造性（G. D. Stoddard），創造性の社会的条件 (H. D. Lasswell), 文化人類学より見た創造性 (M. Mead), 展望 (H. H. Anderson).

各専門分野から種々の問題が提出されているが, Maslow は，ここで 15 年来の自分の考方方を改めなければ ならないといっている，精神的な健康，天才，生産性は 同義語だと，従来，かれが主張していたが，これは事実 ではない. Maslow が調べてきた対象の大部分は健康で 創意のある人たちであって，天才でも芸術家でもなかっ た. ゴッホ，ドガ，バイロンなどとめげていけば，健康 そ特殊な才能とは異なる変数であるといらほかない。そ こで，「特殊な才能の創造性」と「自己実現の創造性」 (self-actualizing creativeness) を区別し，もっぱら後 者だけを議論するというのである，とすれば，日常生活 に直接結びついたことがらを扱うことになり，子供から 成人まで，すべての人に共通した創造の可能性を探りあ てることができる. Sinnottによれば，創造性は生活そ のものであり, Dow は生活の仕方, Rogers は自由な経 験(openness to experience), Anderson は最もらさわ しい社会生活にほかならないという。これらの議論は,

創造の所産ではなくて創造の過程に集中するが，この点 は, 良くも悪くも，かつての哲学的な創造論に対する最 近の議論の特徵である。これは，創造活動を一般的な能 力に還元することにもなる．化学者 Eyring と社会学 者 Lasswell だけがこの還元に反対している.

創造力の構造を考兵た Guilford は，このシンポジウ ムに出席することができず，かれの論文はこの書物のた めとくに執筆されたものである. Guilfordを中心とし
た創造性に関する研究は，発表されるごとに少しずつ相 異しているが, この論文では創造力の特性として, 問題 を受け取る能力, 思考の円滑さ, 思考の柔軟さ, 独自 性, 再構する能力, 工夫する努力の 6 つがあげられてい る. Hilgard はこの考光に対し批判的であって, 情動的 な因子をも見つけ出した研究 (Gough，1957）の方が優 れているとい5. Hilgard はまた問題解決を思考過程あ るいは学習過程として研究したものには, 創造性につい ての示唆を見出し得ないとし, (これは心理学と論理学の

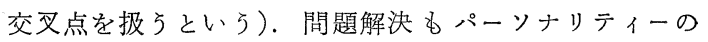
要因との関係から考光て, 集団から独立した者 (nonconformist) の方がよりよい問題の解決者であるという.

Guilford を除けば，すべての論者が創造を促進した り制約したりする環境的条件にふれている. 代表的な概 念を示すならば，創造に都合のよい環境は「オープン・ システム」である(Anderson). Eyring は Berkeley の Lewis の教室を例にあげる. 3 人のノーベル賞受賞者 を輩出したこの教室は，よく例に引かれるらしいが，通 常の講義を止めてしまってまで研究を重視するところで ある. 大学院の学生が国際的にも著名な科学者と一緒に なって研究に当り, 研究の成功は, 過去の科学に対する 過度の尊重を払拭することを伴う。（Lewis のセミナー ではいつも活発な論争が展開され, 黒板はタバュの青い 煙の中にかすんでいたという.) Hilgard は，「二年生の スランプ」に論及し, 集団的な視準に従う批判力は創造 的な活動を阻害する扮とれが女ることを指摘する. Stoddard は自ら試みた小学校教育の計画について述べ, 種 々の知識の集積ではなく, 人間性の成長と創造性を羪う ことを強調する． Lasswel は創造の過程を革新と承認 であると定義する，社会的な承認の仕方如何が，革新を 促進させるものとなる。 Mead は Samoa, Arapesh, Manus, Bali を比較して, 文化梯式とその文化の中に 生活する個人の創造性との関係を述べる。Samoa では 自由はあるのに新しいものはごくわずかしか加えられず 平凡な繰り返しを喜んでいる，Arapesh では同様に自 由でありながら様式を欠くために創造の所産を支えるる のがない. Manus ではやはり様式を欠くが外向きで絶 えず新しい経験に向う。しかしすぐに一般的な紋切型を 形成するだけで終る、Bali では Samoa と同じょうに， 一定の様式を持った閉ざされた文化であるが，誰もが音 楽家，芸術家であるようなこの楽園では，ごくわずかな 新しさの創造で満足できなくなり，過程としての創造性 よりる所産に対する評価によって創造性を認めなければ ならなくなってきた。自由なだけでは創造は生まれな い. 他方人間は真理の発見だけに喜びを感ずるわけでは なくて，身辺の事物についてのわずかな発見にも喜びを 得る. Meadは Edith Cobb, Margaret Lowenfeld を あげて，身辺の事物との結びつき（cosmic sense とい 
う）を満足させようとする研究の重要性を示唆してい る。

Murray は文化史的考察を加兄て，13 世紀の西欧文 化はビシュヌの時代で統一されていたが，フランス革命 を境にシバの時代が訪れ破買的になり, 現在はブラーマ の時代で創造のための創造を必要とするという。

創造過程の中心問題はいわゆるインスピレーションで むるが，このような現象的過程の説明はポアンカレの域 を出ない，数人の論者が共通して示しているのは，イン スピレーションが仕事への熱中と不可分であるというこ そである。その中で, Maslow は「絶頂感」（peak-experience）の研究に移り，このような状態に扔いては， 経験に対して解放的になり，より自発的になり，十分な 自己実現が可能になることを示そうとする。これは禅の 俉りにも通ずるといっている.

創造性と無意識の関係については, Anderson が「展 望」の一節をさいて論じている. Anderson によれば, 無意識は真の自我が非情な世界から一時逃げ出すことの できる場所であり, 画家はアトリエに引きこもり, 科学 者は実験室のドアを閉ざして, ありきたりの保守的な思 考の型を斥けようとする. 子供でさえる, 時々一人きり でいられるような家の一隅を必要とする. 社会の中の真 の自我は防衛的に振舞わなければならない，とすれば, 馬車に乗ろうとした時, 雨の中を歩いている時などは, 一時的に文化の脅威から逃れているわけで，この時イン スピレーションがひらめくのは不思議ではないという。 理想的な創造の条件は, 社会的なるのと個人的なるのを 綜合した体制であるとする。

しかし，個人的なものと社会的なものとはこのように 現象的に区別することはできない，綜合は理想ではなく て, 現実に進行している. 文化の中に生きながら, しか も文化から分裂する創造は, 個人と社会の伝統的な二元 論では解明できそうにない。

\section{東京工業大学 䵸山貞登}

\section{創造性と心理学的健康（シンポジウム）}

\section{Michael F.Andrews, editor}

(Creativity and psychological health. Syracuse University Press, 1961, pp. 148.)

10 の論文からなる. 創造性についての総論 (P. A. Sorokin), 創造過程の次元 (L. A. Fliegler), 創造性と 精神的健康は両立するか (R. H. Ojemann), 創造とコミ ニニケーション (R. L. Mooney), 創造性とシンボリズム (C.F. Virtue), 創造性, 同調性, 自我 (C. Moustakas), 創造性と精神的健康についての対話 (M. F. Andrews), 健康な人の創造的はけ口 (O. Tead), 生物学的非適応,
教育, 創造性 (G. A. Cronk), 創造的教育方法の基礎 (V. Lowenfeld).

このシンポジウムは創造的美術教育に関する 1960 年 の会議として行なわれたもので, 最後の論文は Lowenfeld の遺稿になった.

Sorokin の総論は，括そらく社会学者であるためもめ つて，心理学の通常の概念とは相違するところが少なく ない。たとえば，認知と創造の統合理論であるとして， a) 超意識的な天才むるいは直観，b）合理的な論理数 学的思考, c) 感覚的知覚括よび観察, を構成要素とす るのは, 別記の Guilford と比べて有効であるとは思わ れない, 超意識(superconscious or supraconscious)は 意識の上位にあって超理性的一超感覚的であるとの意味 で名付けられたもので，数学者のガウスが「神の恩籠」 と呼んだものに相当する。しかし，このような，特別の 意識を仮定する必要は感じられない。ただ一般の知性に 帰し得ないるのの存在を論証すべきであるが，これにつ いては, エピソードをあげるに止まっている。

Fliegler は創造の次元を考光, 上位から, 宇宙の創 造，人生の創造，投射的創造，問題解決の創造，複雑な 選択的創造, 単純な選択的創造, 単純な習慣的創造, と する，創造性は一次的な動因であるとるい5．創造活動 の種類を分けることはこの問題の整理になろう。しか し，この次元山るいはレベルと呼ばれたものは仕事の程 度を示すとされ, 必ずしも心理学的な過程の特質によっ たものではない、またワラスの 4 段階説（準備期，あた ため期，啓示期，検証期）に対しては，その準備期に当 るところを 3 分して, 行動的反応の解発, “一次的な創 造の動因”と“間題を解こうとする社会的な要求”との 結合, 問題の把握, とする。検証期の後には, 再構成と 再評価の段階を加える. 別記のシンポジウムでも，心理 学的過程としての創造性に重点が置かれていたが，その 趣旨を受けついで, Flieglerは，木だ明らかでない過程 を記述しょうとしたのである。しかし創造過程の中心問 題は，前後の段階よりは，あたため期と啓示期にある。 あるいは, ワラスの段階説の批判者がいうように，必ず しも段階を構成しない全人格的な活動であることにある。

Ojemann は，ゴッホやベートーベンの異常な行動は, すべて社会の側に原因があることを強調する。われわれ の社会には，創造のポテンシャルを十分に発揮すること を妨げるような，多くの障害が存在している，プランク の自伝によると，かれの量子仮説は，当時権威者の間で は全く認められず，かれとは研究分野を異にするボルッ マンなどの原子論によって（プランクは，ボルッマンに 対して，反対者側に立って論争したこともある）支持を 受けたのでめり，自伝の文章では，「新しい科学の真理 が勝利を扣さめるのは, 反対者を説得することによって ではなくて，反対者が事故で死亡することによってであ 
る」と表現するほどであった。しかし，Ojemann がす ベての異常行動の原因を, ゴッホと恋人, ベートーベン と父親, プランクと権威者のような社会的コンフリクト (衝突）とする点は，認めることができないように思 5 .

Virtue は, シンボリズムのないところに創造はない という。シンボルは, 事実と価值, 合理的なるのと非合 理的なるのとを結合する。作曲家 Finney の経験を例に とると, はじめに, ある「けはい」(gesture) が意識に 現われた。これは，はっきりした運動とか視覚的パタン ではなくて，内的に聞こえる音のけはいであった。二度 ほどこのけはいを音楽に書きとめようと試みたが失敗に 終ったので, しばらくは諦めていた。その後ふたたび音 のけはいが感じられ, 今度は一部分音楽の形に記すこと に成功した：それから，突然にアイディアがひらめい た、このアイディアは以前に完成した作曲から思いつい たものであった。そこで草稿を書き始めたところ，「想 像の水門が開かれ，はじめの音の忷はいを音楽にするこ とができた」という，Virtue の説明によると，「もとも との衝動と二次的なアイディアとの間の一般的な構造が 把握されたとき」, 創作的な表現ができるという。Virtue の考えの基礎にはJung の古態型の理論と Cassirer のシンボルの理論がある。

Teadの論旨は, 別記のシンポジウムに拉けるMaslow の理論を全面的に支持したものである。Tead は内向き のパーソナリティーを理解することを中心問題とする. ゲーテがファウストを創造したのではなくて，ファウス トがゲーテを創造した，といらユングの言葉も銘記する 必要があるという、極端な形では, 過程の方が人間を左 右し，このような状沅では，パーソナリティ一の力は倍 加されることになる.

Lowenfeld の創造理論の要点はつぎのようなるので める.人間と動物の違いは, 人間は自分の意志によって 創造するが，動物はそうではない点にある。人間は誰で もポテンシャルとしての創造力を持つが，その創造力を いつも十分に発揮するとは限らない。そこで, 潜在的創 造性と機能的創造性を区別し, 教育の任務は, 個人の創 造的なポテンシャルを現実に㗢かせるよう解発すること である. その目標は潜在的創造性と機能的創造性とが平 衡を保つ点であり, なた, 社会的地位や個人的能力とは 関係なく, 各人の創造的ポテンシャルをぞの程度まで解 発することができるかは, 社会の倫理によってきまると 思う，という。

そこで教育は,つぎの 4 種の感受性を発達させること をねらいとする．知覚の感受性あるいは感覚の利用のし かたが洗鍊されていること、美的な感受性あるいは調和 に対する感受性. 情動的和よび社会的な感受性. Lowenfeld は情動的な感受性と社会的な感受性を分離するこ
とは難しいという．作家と作品とは一体となっている．

この論点は興味深い. 一般に心理学では, 個人と社会 の対立を解消するものとして社会化の過程を問題とする が，別の意味でこの対立を解消するのが創造過程の特徵 であろう。「社会的」といら言葉の定義の仕方にすぎな いといわれるかもしれないが，少くとも，この上5な見 地は成立する。

最後に, Lowenfeld は, 知的な感受性についても論及 している、これは美術教育があ屯りに知能を無視するこ とをいるしめたものである。他に，適応の柔軟性，綜合 力, 独自性のための独自性の批判, 持論である美術教育 の意義も論じられている.

\section{東京工業大学 䵷山貞登}

\section{産業関係の創造性}

\section{Eugene Von Fange}

(Professional Creativity. A new and timely analysis of creative thinking. Englewood Cliffs, N. J. : Prentice-Hall, 1959, pp. 260.)

経営合理化や企業間, 国際間の技術競争の激化は, こ の数年来にわかに, 産業界に拈ける創造的研究活動の與 隆をもたらした。しかし, 心理学は, M.R., 広告効果 測定, 人事管理, Moral Survey などの分野ではかなり の成果を示しつつあるものの，この創造性研究には，未 だ本格的な分析を加光るに至っていない。むしろ，今日 では，現場の技術者の実践に基づく報告の中に見るべき ものが多い、本書もとの一つである. 著者の Von Fange は, ネブラスカ大学で電気工学を修め, 現在, ゼネラル エレクトリック社の技師で創造性セミナーの指導をして いる. 彼は, そこで得た多くの体験にもとづいて本書を 著わした，本文 16 章と附録 2 章からなる本書の中では, 創造的活動を好げる諸要因の分析々，それを克服して創 造性を十分に発揮させるための研究計画とが，豊富な具 体例や懇切な忠告, さらには気のさいた警句までもつけ て展開される。

1 章「創造を理解する」 2 章「思考への挑戦」では, 創造と思考の概念が検討される。彼は, 創造を, 「既存 の諸要素をその人にとって新しい仕方で結びっけるこ と」と定義する。一方思考は「判断・概念化・推理の力 を用いてする，目的を目指した積極的な活動」であり， 「新しい連合を生及評価すること」でもめるから，それ は, 「心的に方向づけられた創造作用」ということにな る. 彼によると, この創造力は万人に具わっているもの であり，それが十分に発揮されないのは，いろいろな要 因によって抑圧されているからなのである。そこで, 著 者は，3章「障害と特効薬：技法」4 章「諸技法」で, その妨害要因を分析し，それらをとり除く既存の技法を 
紹介する. 習慣, functional fixedness, 周因の無理解な ぞを，個人的，対人的妨害因であるとし，これを除いて 創造性をたかめる技法に，（1）興味を方向づける 知識をます（3）フィルターを形成する（目的に適し たアイデアを出しつづける）（4）連合をはやめるな ぞ 4 つのカテゴリーがある，と考觉る。攵して，これら 技法の具体例として「経験リスト」「Check List」「Idea Matrix」「難点説明」「Gordon 法」「Brain Storming」 「特かしさ利用」「Gordon-Brainstorming」など 8 技 法をめげて解説する。続く，5章「知識…素材」6 章 「情動と環境」7 章「判断と反省」では, 創造的な仕事 を達成するための一般的注意事項が示される。たとえ ば, 過去の知識を十分に利用してムダを省くため, その 出所と内容のノートをマメにとって执いたり, 雑誌別専 門家を作ったり，一頁抄録を作って配ったりして，知識 を正確に使用できるようにして拓くこと，規則正しいス ケジュールに従って創造的な仕事にかかること, 失敗を 環境のせいにしないで周囲の考方方を改善さすこと，ま た，特殊な知識を一般化したり， illuminationを打こさ せるため, 故意に 2,3 分，頭を他のことに使わせるな ぞして，新しい見方のできるようにすること，などであ る. 8 章「立案と計画」9 章「基本計画」では, 研究者 の能力や経験を生方して産業界で創造的な研究を達成す るためには, 積極的に仕事の手順を決め, 計画し, スケ ジュールを組むことが必要だと強調する。立案は, 目的 をはっきりさせることによって，いろいろなムダや誤解 をとり除くのに役立ち, 一方, スケジュールは，いくつ かの途中しめ切り日を作ることによって, 達成への毉張 を維持させ，効率をめげるのに役立つからである。

彼が，経験にもとづいて立てた基本計画は，I．「研 究者自身の疑点を解決する」II. 「他人の疑点や打それ を予測して，これを少くする」III.「経験をと物して判 断力が高まり，円熟味が增す」といら三段階を含んでい る.この第吕段階は，研究活動からのフィードバックに よって，研究が絶えず改善されていくことを意味してい るが著者の分析は，とくに前の 2 段階に向けられる. 各 段階はさらに時相ずつに細分される。（そのそれぞれが, 本交の 10 章から 15 章玉でのタイトルになる.)

第 1 時相「方向を研究する」では, 注文（問題）を記 録し，目的をはっきりさせ，参与する要因を明解にし， 既存のデータを集めプランを立ててさらに，それを他人 に検討させ，客観的に批判させることによって，研究方 向を決定する。第 2 時相「尺度を測定する」では, 研究 活動についての明細書を作って, goal が達成されたと きを測る尺度を決める。 そのため，明細書には，誰が （責任をるつ，決定する），何が（なされる，与えられ る）いつ(何日まで)，どらなるか（もし，これがうま くいかないと）をはっきり畵き，“最高の”，“モダンな”
“満足すべき”，などあいまいなコトバを使ってはいけな い. 第 3 時相「方法を展開する」では， $1 \cdot 2$ 時相で立 てられた計画に従って，適当な応用データが作られれば よい，それには，問題の目標をさらに細かく分けて，そ れぞれの要素へのアイディアを別々に出し，それらを尺 度に合わせながら進むこと，失敗を細かく記録して，愦 りの重複をされること，いくつかのアイデアからよいの を速く選ぶこと，などが必要である。（このテクニック を養うため，長い問題を完成したあと，それを見て， 二，三分で，解決を予想する練習をする.）ここまでで， 研究者に関する問題は解決される。 しかし, 製品化され るには, 研究者以外の他人に, この解決が受け入れられ なければならない，そこで，第开段階が必要となる。第 4 時相「構造を最適にする」では, 研究者が使用者の立 場に立って，よい第 1 印象が括こるような構造を作らね ばならない（モデル，レポート青写真などで)。第 5 時 相「解決を完成する」では, 創造的な仕事は他人の協力 を要するので, コミュニケーションを巧くし，人間関係 をよくして特か叔ばならない,つまり，研究者は，誠実 で，友好的で正直でューモアに満らていなければならな い. 第 6 時相「他人を信服させること」では，人は新し いものを受け入れるのに抵抗するので, これを除くため の技法として，上手な話し，図表，他との比較などによ って，人に内容をよく理解させること，いいかげんな説 明や行動をとらないこと、などが大切である，と説く。

このような著者の考えの底には，アメリカ人らしい楽 観主義的人間観と，計画や努力によってすべてをなしと げるフロンティア精神が波うっているように思われる。 この態度は, 研究を発展する上に学ぶべきところ大であ るが，本書の内容には，不満な点がないわけではない。 たとえば，思考心理学で一番間題となる第 3 時相や第正 段階の分析が十分でないこと，創造活動を妨害する要因 の細かい条件分析がなされていないことなどが指摘され らる。もっとも，実践を重んじる現場の技術者にこれを 要求するのは筀違いかもしれない。

何といっても，本書は，創造活動に特ける集団思考 や，思考に影響する社会的要因を重視した点で，実験室 的創造性の研究と異った視角をるら，条件分析だけで， わがことなれりとする実験思考心理学者の視野の狭さか らはみ出た現実の世界に，分析さるべき，乙かも，心理 学的に分析可能な数多くの創造的思考に関する問題があ. ることを示してくれる。

な拉，本書は，日本の産業界でも，とくに技術者に高 く評価されつつあるという。この事実は具体的場面での 創造性や思考について, 役立つ, 生きた研究に, 心理学 者も本格的に取り組むことのできる機が熟してきている ことを示すものではなからうか。

\section{東京工業大学 坂元 昂}

